\title{
Työn intensifikaation profiilit suomalaisilla johtajilla: Yhteydet työhyvinvointiin ja työnkuvan vaihtoajatuksiin
}

\begin{abstract}
Abstrakti
Tutkimuksessa selvitettiin, millaisia työn intensifikaation eli työn kiihtymisen profiileja voidaan tunnistaa johtajilla ja miten eri profiilien johtajat eroavat toisistaan työhyvinvoinnin ja työnkuvan vaihtoajatusten suhteen. Kyselytutkimuksen otos poimittiin Professoriliiton, Tieteentekijöiden liiton, Suomen Ekonomien ja Tekniikan Akateemisten jäsenrekistereistä. Tutkituista johtajista $(N=705)$ yli puolet (56 \%) oli miehiä. Löysimme K-keskiarvojen klusterianalyysin avulla viisi profiilia: 1) Riskiprofiili (voimakas työn intensifikaatio, 31 \%), 2) suotuisa profiili (työn- ja urasuunnittelun vaatimukset lisääntyneet kohtuullisesti, $19 \%$ ), 3) haitta- ja haastestressoriprofiili (työtahti ja tieto- ja taitovaatimukset lisääntyneet, $20 \%$ ), 4) alhainen profiili (vähäinen työn intensifikaatio, 22 \%) ja 5) haasteeton profiili (ei työn intensifikaatiota, 8 \%). Riskiprofiilin sekä haitta- ja haastestressoriprofiilin johtajat raportoivat eniten työuupumusta. Haitta- ja haastestressoriprofiilin johtajilla oli eniten toiveita päästä vähemmän vaativiin johtotehtäviin. Suotuisan profiilin johtajilla oli paljon työn imua ja vähän työnkuvan vaihtoajatuksia. Yhteenvetona voidaan todeta, että puolet johtajista kuului työn intensifikaation suhteen vaativiin ryhmiin (1 ja 3), joissa ilmeni muita ryhmiä enemmän työuupumusta sekä toiveita vähemmän vaativista johtotehtävistä.
\end{abstract}

\section{Johdanto}

Työelämän tahti on kiihtynyt huomattavasti viimeisen muutaman vuosikymmenen aikana (Kubicek, Paškvan \& Korunka 2015; Paškvan, Kubicek, Prem \& Korunka 2016). Globalisaatio, lisääntynyt kilpailu yritysten välillä sekä teknologiset muutokset johtavat kasvaneisiin suoritusodotuksiin organisaatioissa (Landsbergis 2003; Valeyre 2004). Tällaiset muutokset työelämässä kasaavat suorituspaineita organisaatiossa työskenteleville henkilöille sekä johtavat työn intensifikaatioon eli kiihtymiseen (Kubicek ym. 2015). Monissa viime vuosikym- meninä tehdyissä tutkimuksissa onkin havaittu työntekijöiden kokevan työn intensifikaatiota (Burchell, Ladipo \& Wilkinson 2002, 61-76; Green \& McIntosh 2001; Paoli \& Merllié 2005, 3). Työntekijöiden kokemukset voimakkaasta työn intensiteetistä ovat yleisiä Euroopassa ja erityisesti esimiehet sekä asiantuntijat kokevat voimakasta työn intensiteettiä (Eurofound 2017).

Työn intensifikaatio sisältää eri ulottuvuuksia. Tutkimuksemme tavoitteena on profiloida johtajia erilaisiin ryhmiin heidän työn intensifikaatiota koskevien kokemustensa perusteella. Lisäksi vertailemme eri profiileja 
omaavia johtajia keskenään heidän työhyvinvointinsa (työuupumus, työn imu) ja työnkuvan vaihtoajatustensa (hakeutuminen vaativampiin/vähemmän vaativiin johtotehtäviin tai kokonaan pois johtotehtävistä) suhteen. Tutkimuksemme kohdistuu johtotehtävissä toimiviin professoreihin, tieteentekijöihin, ekonomeihin ja tekniikan akateemisiin. Professorit ja tieteentekijät työskentelevät yliopistoissa, korkeakouluissa ja tutkimuslaitoksissa, kun taas ekonomit ja tekniikan akateemiset pääosin yksityisellä sektorilla. Aikaisemmissa tutkimuksissa on havaittu yksityisellä sektorilla työskentelevien kokevan enemmän työn intensifikaatiota (Eurofound 2013; Green \& McIntosh 2001), mutta toisaalta Hakalan, Kaukosen, Niemisen ja Ylijoen (2003, 90-93) tutkimus osoitti yliopistoissa tieteentekijöiden kärsivän kiireestä ja kohtuuttomiksi koetuista työtaakoista. Tutkimuksen puutteen vuoksi onkin tarpeellista tutkia, eroavatko yksityisellä ja julkisella sektorilla työskentelevien johtajien työn intensifikaation kokemukset toisistaan. Koska johtajat ovat suuressa vastuussa organisaation tuloksellisuudesta (Little, Simmons \& Nelson 2007), on lisäksi tärkeää tutkia johtajien kokemaa työn intensifikaatiota ja sen yhteyksiä työhyvinvointiin sekä työnkuvan vaihtoajatuksiin. Tutkimuksessamme käytämme uudenlaista, työn intensifikaatiota mittaavaa kyselymenetelmää (Kubicek ym. 2015), joka antaa työn intensiivistymisen eri ulottuvuuksista tietoa. Työn intensifikaation ulottuvuuksia tutkimalla saamme laajemman käsityksen johtajien työn intensifikaation kokemuksista ja työelämän kiihtymisestä, eikä tutkimus rajoitu vain yleisiin havaintoihin sosiaalisesta kiihtymisestä yhteiskunnassa.

\section{Työn intensifikaation käsite}

Uudet teknologiat, globalisoituneet markkinat ja organisaatiomuutokset luovat haasteita organisaatioille ja muuttavat työntekijöiden työolosuhteita (Cascio 1995). Näiden globaalien muu- tosten vuoksi työn intensiteetti onkin lisääntynyt viimeisen 40 vuoden aikana (Brown 2012). Työn intensifikaation käsite kuvaa työntekijän itsearviota/subjektiivista kokemusta työn intensiteetin lisääntymisestä (Franke 2015). Työn intensifikaatiota ilmenee, kun työntekijät kokevat painetta suorittaa loppuun enemmän työtehtäviä työpäivän aikana (Kubicek, Korunka, Paškvan, Prem \& Gerdenitsch 2014, 25-41). Työn intensifikaation seurauksena yhä useammat työntekijät joutuvat työskentelemään kiihtyneellä tahdilla tiukoissa aikarajoissa (Green \& McIntosh 2001), suunnittelemaan ja tekemään päätöksiä työssään itsenäisemmin (Pongratz \& Voß 2003) sekä hankkimaan jatkuvasti uutta tietoa työhön liittyen (Loon \& Casimir 2008).

Rosa (2013, 20-70) on esittänyt sosiaalisen kiihtyvyyden käsitteen sosiaalisessa viitekehyksessä, johon työn intensifikaation käsite pohjautuu. Sosiaalinen kiihtyvyys on laaja-alainen ilmiö yhteiskunnassa. Siihen kuuluvat muun muassa muutokset ajankäytössä (Garhammer 2002) sekä ajanhallinnan paineet (Szollos 2009). Ilmiö ulottuu myös työelämään, jossa se näkyy lisääntyneenä työn intensiteettinä ja subjektiivisena kokemuksena työn kasvaneista vaatimuksista (Ulferts, Korunka \& Kubicek 2013). Sosiaalinen kiihtyvyys lisää työntekijöille tehostettuja vaatimuksia omaa työtään kohtaan, mikä johtaa työn intensifikaatioon (Rosa 2003; Ulferts ym. 2013).

Tutkimuksemme perustuu Kubicekin ja kollegoiden (2015) kehittämään työn intensifikaation malliin, joka koostuu viidestä eri osaalueesta. Ensimmäinen osa-alue on työtahdin kiristyminen, jota luonnehtivat tarve työskennellä kiihtyneellä tahdilla, suorittaa useita tehtäviä samanaikaisesti sekä tarve vähentää joutilasta aikaa työssä (Paškvan ym. 2016). Empiiriset tutkimukset (Obschonka, Silbereisen \& Wasilewski 2012; Pongratz \& Voß 2003) sekä Rosan $(2013,20-70)$ teoria sosiaalisesta kiihtyvyydestä osoittavat työtahdin kiristyneen työelämässä. Toinen osa-alue on lisääntyneet työnsuunnittelua ja päätöksentekoa koskevat vaatimukset. Cascion (2003) 
näkemyksen mukaan sosiaalinen kiihtyvyys johtaa organisaatioissa nopeutuneisiin päätöksentekoprosesseihin. Tämän seurauksena Kubicekin ja kollegoiden (2015) mukaan organisaatiot vähentävät työntekijöihin kohdistunutta suoraa kontrollia ja lisäävät autonomisen päätöksenteon ja suunnittelun vaatimuksia. Kolmas työn intensifikaation osaalue on lisääntyneet urasuunnitteluun ja sitä koskevaan päätöksentekoon liittyvät vaatimukset (Kubicek ym. 2015). Työntekijöiden täytyy jatkuvasti osoittaa arvonsa nykyiselle työnantajalle sekä ylläpitää omaa työmarkkina-arvoaan tulevaisuuden varalta myös organisaation ulkopuolella (Briscoe \& Hall 2006; Pongratz \& Voß 2003). Tämä voi liittyä siihen, että työelämässä pitkään vallalla ollut pysyvä ja lineaarinen urapolku on muuttunut monisuuntaisempaan ja dynaamisempaan urapolkuun, jossa työntekijöitä eivät motivoi enää yhtä paljon lojaalius työnantajaa kohtaan, vaan sen sijaan heitä motivoivat omat tavoitteet ja arvot (Baruch 2004). Omien tavoitteiden ja arvojen korostuminen työelämässä saattaakin vaikuttaa myös lisääntyneeseen urasuunnitteluun. Neljäs osa-alue, lisääntyneet vaatimukset hankkia uutta tietoa, viittaa vaatimuksiin sekä päivittää jatkuvasti työhön liittyvää vanhaa tietoa että kehittää omaa osaamistaan. Tämä on seurausta yritysten tarpeesta pysyä kilpailukykyisinä, sillä tieto on tärkeä taloudellinen voimavara (Loon \& Casimir 2008; Pyöriä 2005). Viides osa-alue on lisääntyneet vaatimukset hankkia uusia taitoja (Kubicek ym. 2015). Työntekijöiden täytyy mukauttaa taitojaan uusien laitteiden ja ohjelmien käytössä, työkäytännöissä sekä työskentelytavoissa (Ulferts ym. 2013).

Työn intensifikaatiota on tutkittu eri ammattiryhmissä, kuten opettajilla ja vanhustenhoidon työntekijöillä (Droogenbroeck, Spruyt \& Vanroelen 2014; Korunka ym. 2015) sekä julkisella ja yksityisellä sektorilla työskentelevillä (Le Fevre, Boxall \& Macky 2015; Omari \& Paull 2015), mutta ei toistaiseksi korkeasti koulutetuilla johtajilla. Green ja McIntosh (2001) havaitsivat analysoimalla Euroopan työolo- suhdetutkimuksia vuosilta 1991 (12 maata) ja 1996 (15 maata), että yksityisellä sektorilla työskentelevät henkilöt kokevat työn intensifikaatiota enemmän kuin julkisella sektorilla työskentelevät. Toisaalta Le Fevren ja kollegoiden (2015) Uudessa-Seelannissa vuosina 2005 ja 2009 toteutettujen tutkimusten mukaan julkisella sektorilla työskentelevät henkilöt kokivat enemmän stressiä. Lisäksi heidän tutkimuksensa mukaan asiantuntijat raportoivat enemmän työn intensifikaatiota kuin muut tutkimukseen osallistuneet ammattiryhmät. Hakalan, Kaukosen, Niemisen ja Ylijoen (2003, 90-93) suomalaisten yliopistojen tieteentekijöitä tarkastellut tutkimus osoitti, että kiire, kohtuuttomaksi koetut työtaakat ja riittämätön perusrahoitus vaikeuttavat tutkimustyötä. Lisäksi 34:ssä Euroopan maassa tehty työolosuhdetutkimus osoitti miesten kokevan naisia enemmän työn intensiteettiä (Eurofound 2013). Toisaalta EU-maissa sukupuolten väliset erot työn intensiteetin kokemisessa ovat vuosien 1991 ja 2000 välillä pienentyneet, sillä työn intensiteetin kasvu on ollut voimakkainta naisilla (Burchell \& Fagan 2004). Maunon, Minkkisen, Tsuparin, Huhtalan ja Feldtin (2019) tutkimus ylemmillä toimihenkilöillä osoitti iäkkäämpien työntekijöiden kokevan enemmän työn intensifikaatiota sekä lisääntyneitä tieto- ja taitovaatimuksia, kun taas nuoremmat työntekijät kokivat lisääntyneitä uraan ja päätöksentekoon liittyviä vaatimuksia.

Tavoitteenamme on profiloida johtajia erilaisiin ryhmiin heidän työn intensifikaation kokemustensa suhteen, mikä on uusi lähestymistapa työn intensifikaation tutkimukseen. Henkilösuuntautuneessa lähestymistavassa (ks. Bergman \& Lundh 2015) otoksesta identifioidaan osajoukkoja (profiileja), jotka saavat erilaisia muuttujien arvoja (Meyer \& Morin 2016). Henkilösuuntautuneen lähestymistavan avulla pystymme tutkimaan, minkälaisia työn intensifikaation profiileja johtajista on tunnistettavissa ja miten johtajien työhyvinvointi sekä työnkuvan vaihtoajatukset eroavat eri työn intensifikaation profiileissa. 


\section{Työn intensifikaation yhteys työhyvin- vointiin ja työnkuvan vaihtoajatuksiin}

Työhyvinvoinnin kuvaajina tutkimme työuupumusta ja työn imua. Työuupumus on oireyhtymä, jota kuvaavat 1) uupumusasteinen väsymys (tunne kuormituksesta ja kroonisesta väsymyksestä), 2) kyynisyys (välinpitämätön asenne työtä kohtaan ja työn kokeminen merkityksettömänä) sekä 3) heikentynyt ammatillinen itsetunto (vähentynyt kompetenssin ja suoriutumisen tunne) (Maslach, Schaufeli \& Leiter 2001). Työn imu on positiivinen työhön liittyvä mielentila, jota luonnehtivat tarmokkuus, omistautuminen ja uppoutuminen (Schaufeli, Salanova, Gonzáles-Romá \& Bakker 2002).

Käytämme LePinen, Podsakoffin ja LePinen (2005) kehittämää haaste- ja haittastressoreiden teoreettista viitekehystä tehdessämme oletuksia työn intensifikaation yhteyksistä työhyvinvointiin. Haastestressori määritellään työhön liittyväksi vaatimukseksi, johon liittyvät esimerkiksi oppimismotivaatio, aikapaineet, suuri työmäärä ja vastuullisuus (Cavanaugh, Boswell, Roehling \& Boudreau 2000). Vaikka haastestressorit ovat potentiaalisesti stressaavia, ne edistävät henkilökohtaista kasvua aktivoimalla positiivisia emootioita sekä hyvien ongelmanratkaisukeinojen käyttöä. Haastestressorit motivoivat yksilöä, sillä niiden avulla voidaan saavuttaa haluttuja lopputuloksia (LePine ym. 2005). Esimerkiksi kyproslaisia hotellityöntekijöitä käsitellyt tutkimus osoitti, että haastestressorit lisäsivät työntekijöiden kokemaa työn imua (Karatepe, Beirami, Bouzari \& Safavi 2014).

Haittastressorit sisältävät stressaavia vaatimuksia, kuten roolien monitulkintaisuutta sekä organisaation politiikkaa, josta saattaa seurata henkilökohtaisen kasvun estymistä sekä negatiivisia tunteita. Haittastressorit yhdistetään alhaiseen motivaatioon, sillä ponnisteluista huolimatta niiden asettamat vaatimukset ja niiden täyttyminen koetaan vaikeaksi (LePine ym. 2005). Korunkan ja kollegoiden (2015) tutkimuksen mukaan työn intensifikaatio on haittastressori, joka saattaa aiheuttaa työntekijälle uupumusasteista väsymystä.

Työn intensifikaatio sisältää aikavaatimuksia, jotka voidaan kokea joko haaste- tai haittastressoreina. Haaste- ja haittastressoreiden teoreettisen viitekehyksen mukaan kohtuuttomat aikavaatimukset työssä ovat haittastressoreita, kun taas työntekijälle itselleen sopivat aikavaatimukset ovat haastestressoreita. Tutkimus suomalaisten terveydenhuollon ammattilaisten kokemasta työn imusta osoitti, että kohtuulliset aikavaatimukset ennustivat voimakasta uppoutumista työhön (Mauno, Kinnunen \& Ruokolainen 2007). Edellä mainitun tutkimuksen mukaan vasta suhteellisen korkeat aikavaatimukset työssä aiheuttavat negatiivisen vaikutuksen työn imuun (emt.). Oletamme siis, että johtajien profiileissa, joissa koetaan kohtuullisesti työtahdin kiristymistä, esiintyy enemmän työn imua, kun taas johtajien kokiessa erittäin paljon työtahdin kiristymistä heillä esiintyy vähemmän työn imua.

Lisääntyneet vaatimukset hankkia uutta tietoa sekä uusia taitoja liittyvät haaste- ja haittastressoreiden yhteydessä tutkittuun oppimissuoritukseen ja oppimismotivaatioon sekä tehostettuun oppimiseen. Erään yliopistoopiskelijoiden parissa tehdyn tutkimuksen mukaan haittastressorit olivat negatiivisesti ja haastestressorit positiivisesti yhteydessä oppimissuoritukseen sekä oppimismotivaatioon (LePine, LePine \& Jackson 2004). Sekä haaste- että haittastressorit olivat positiivisesti yhteydessä työuupumuksen osa-alueeseen, uupumusasteiseen väsymykseen. LePinen ja kollegoiden (emt.) tutkimus osoittikin, että vaikka haastestressorit voivat olla motivoivia ja edistää oppimissuoritusta, tällaisella stressillä voi olla myös kielteisiä vaikutuksia yksilön hyvinvointiin.

Lisäksi työhön liittyvän tehostetun oppimisen yhteyttä työtyytyväisyyteen on tutkittu vanhushoidon työntekijöiden parissa haasteja haittastressoreiden näkökulmasta. Tutkimuksen mukaan tehostettu oppiminen oli positiivisesti yhteydessä työtyytyväisyyteen sekä negatiivisesti yhteydessä emotionaaliseen uu- 
pumukseen tulevaisuudessa. (Korunka ym. 2015.) Korunka ja kollegat (emt.) pohtivat tutkimuksessaan, että jos tehostuneet oppimisvaatimukset liitetään voimakkaasti työn intensifikaatioon, tehostuneen oppimisen myönteiset vaikutukset vähenevät ja oppimisesta muodostuu haittastressori. Esimerkiksi Paulsson, Ivergård ja Hunt (2005) tutkivat kolmen eri yrityksen työntekijöitä ja osoittivat, että lisääntyneet uusien taitojen ja siten tehostetun oppimisen vaatimukset kasvattavat työmäärää. Tehostetun oppimisen negatiivinen vaikutus suureen työmäärään selittyy sillä, että työntekijöillä ei ole ylimääräistä aikaa oppimisprosessille, vaan oppimisen täytyy tapahtua olemassa olevan työajan puitteissa (emt.). Oletamme, että johtajien kokiessa haittastressoreiden aiheuttamia lisääntyneitä vaatimuksia hankkia uutta tietoa sekä uusia taitoja heillä esiintyy enemmän työuupumusta ja vähemmän työn imua.

Lisääntyneitä työhön sekä urasuunnitteluun liittyviä vaatimuksia ei ole tutkittu haaste- ja haittastressoreiden teoreettisen viitekehyksen yhteydessä. Sen sijaan Warrin (1987) esittämän vitamiinimallin mukaan työn autonomialla on epälineaarinen yhteys työhyvinvointiin, jolloin optimaalinen määrä autonomiaa lisää työhyvinvointia ja liiallinen autonomia vuorostaan heikentää sitä. Oletamme, että johtajien kokiessa runsaasti lisääntyneitä työn- ja urasuunnittelun vaatimuksia ne voivat näyttäytyä haittastressorina, jolloin johtajat kokevat enemmän työuupumusta.

Tutkimme myös, missä määrin eri profiilien johtajilla on työnkuvan vaihtoajatuksia, joita tutkittiin kolmella kuvaajalla: hakeutuminen pois johtotehtävistä, hakeutuminen vähemmän vaativiin johtotehtäviin ja hakeutuminen vaativampiin johtotehtäviin. Työnkuvan vaihtoajatuksia on tutkittu haaste- ja haittastressoreiden näkökulmasta (Cavanaugh ym. 2000). Yhdysvaltalaisia ja eurooppalaisia johtajia tarkastelleissa tutkimuksissa on havaittu haastestressoreiden olevan negatiivisesti ja haittastressoreiden positiivisesti yhteydessä työnhakuun (Bingham, Boswell \& Boudreau 2005; Cavanaugh ym. 2000). Johtajat pyrkivät siis lähtemään työtilanteista, joissa työn vaatimukset ovat rajoittavia, mutta toisaalta he näkevät kehittävät työn vaatimukset hyödyksi itselleen (Bingham ym. 2005). Oletammekin, että johtajien profiileissa, joissa koetaan paljon työn intensifikaation eri ulottuvuuksissa esiintyviä haittastressoreita, esiintyy enemmän työnkuvan vaihtoajatuksia.

\section{Tutkimuskysymykset ja hypoteesit}

Tutkimuskysymyksemme ja hypoteesimme ovat seuraavat:

1. Millaisia työ intensifikaation profiileja voidaan tunnistaa suomalaisilla johtajilla?

H1. Koska työn intensifikaation profiilien identifioiminen heterogeenisesta joukosta johtajia on analyyttiseltä otteeltaan eksploratiivista, emme voi asettaa tarkkoja hypoteeseja tunnistettavien profiilien lukumäärästä tai niiden sisällöstä. Oletamme kuitenkin, että tutkittavat johtajat eivät koe työn intensifikaatiota homogeenisesti, ja siksi voidaan tunnistaa erilaisia profiileja, joissa työn intensifikaatio vaihtelee osa-alueittain (H1a). Edelleen oletamme, johtajien työn korkeat vaatimukset huomioiden, että työn intensifikaation kokeminen voimakkaana on yleisempää kuin se, että sitä ei koettaisi tai koettaisiin hyvin vähän (H1b).

2. Miten työn intensifikaation profiileiltaan erilaiset johtajat eroavat toisistaan työhyvinvoinniltaan (työuupumus ja työn imu) ja työnkuvan vaihtoajatuksiltaan?

H2a. Johtajat kokevat enemmän työuupumusta sekä työnkuvan vaihtoajatuksia, jos heidän profiileissaan korostuvat työn intensifikaation eri ulottuvuuksissa esiintyvät haittastressorit (stressaavat työn vaatimukset) 
H2b. Johtajat kokevat enemmän työn imua ja vähemmän työnkuvan vaihtoajatuksia, jos heidän profiileissaan korostuvat työn intensifikaation eri ulottuvuuksissa esiintyvät haastestressorit (motivoivat työn vaatimukset)

\section{Aineisto ja menetelmät}

\section{Aineiston keruu ja tutkittavat henkilöt}

Tämä tutkimus on osa tutkimushanketta, jossa tutkitaan johtotehtävissä toimivien henkilöiden kokemaa työn intensifikaatiota. Tutkimuksen otokset poimittiin 1) Professoriliitton, 2) Tieteentekijöiden liiton, 3) Suomen Ekonomien ja 4) Tekniikan Akateemisten jäsenrekistereistä (ks. Auvinen ym. 2019). Tutkijoiden laatima sähköinen kyselylomake lähetettiin yhteensä 9998 henkilölle, joista yhteensä 2042 (vastausprosentti 20) vastasi kyselyyn. Kysely kohdistettiin ammattiliitoittain työssä oleville 1272 Professoriliiton jäsenelle, joista kyselyyn vastasi 547 (43\%), 3009 Tieteentekijöiden liiton jäsenelle, joista kyselyyn vastasi 690 (23\%), 2820 Suomen Ekonomien jäsenelle, joista kyselyyn vastasi 459 (16\%) sekä 2897 Tekniikan Akateemisten jäsenelle, joista kyselyyn vastasi $346(12 \%)$.

Tutkimme niitä vastanneita, jotka työskentelivät oman ilmoituksensa mukaan johtotehtävissä ja olivat vastanneet työn intensifikaatiota kuvaavaan kyselyyn $(\mathrm{N}=705)$ (Auvinen ym. 2019). Näistä johtajista 362 (51\%) oli professoreja, 91 (13\%) tieteentekijöitä, 164 (23\%) ekonomeja ja 88 (13\%) tekniikan akateemisia. Tutkituista johtajista naisia oli 44 prosenttia $(n=313)$ ja miehiä 56 prosenttia $(\mathrm{n}=392)$. Nuorin johtajista oli 27-vuotias ja vanhin 69 -vuotias $(k a=53$, $k h=8.6$ ). Tutkittavista 92 prosenttia oli pysyvässä työsuhteessa.

\section{Käytetyt kyselymenetelmät}

Työn intensifikaatiota mitattiin 19-osioisella työn intensifikaation kyselyllä (Kubicek ym. 2015), jossa johtajia pyydettiin arvioimaan työssään tapahtuneita muutoksia viimeisen viiden vuoden ajalta. Kysely koostuu viidestä eri osa-alueesta: 1) työtahdin kiristyminen (esim. "Työtehtävien suorittamiseen on ollut entistä harvemmin riittävästi aikaa"), 2) lisääntyneet työnsuunnittelua ja päätöksentekoa koskevat vaatimukset (esim. "Tehtävien suorittamistavoista on pitänyt päättää entistä useammin itsenäisesti"), 3) lisääntyneet urasuunnitteluun ja sitä koskevaan päätöksentekoon liittyvät vaatimukset (esim. "Ammatillista uraa on pitänyt suunnitella entistä useammin itsenäisesti"), 4) lisääntyneet vaatimukset hankkia uutta tietoa (esim. "Työ on edellyttänyt yhä useammin uuden tiedon omaksumista") ja 5) lisääntyneet vaatimukset hankkia uusia taitoja (esim. "Uusiin työskentelytapoihin on pitänyt perehtyä yhä useammin"). Tutkitut arvioivat väittämiä viisiportaisella asteikolla (1 = ei pidä lainkaan paikkaansa, 5 = pitää täysin paikkansa). Muodostimme työn intensifikaatiosta ja sen osaalueista keskiarvosummamuuttujat, joissa suuret arvot kuvaavat korkeaa työn intensifikaatiota. Kuten korrelaatioista on nähtävissä (ks. taulukko 1), kaksi summamuuttujaa - lisääntyneet vaatimukset hankkia uutta tietoa ja lisääntyneet vaatimukset hankkia uusia taitoja - korreloivat erittäin voimakkaasti keskenään $(\mathrm{r}=.81, p<.001)$. Muodostimme niistä siksi jatkoanalyysejä varten yhden kokonaissummamuuttujan, jonka nimesimme lisääntyneiksi tieto- ja taitovaatimuksiksi.

Työиuрumusta mitattiin 9-osioisella Bergen Burnout Inventory -kyselyllä (Salmela-Aro ym. 2011; ks. myös Feldt ym. 2014), jossa mitattiin kolmea ulottuvuutta: uupumusasteista väsymystä (3 osiota; esim. "Tunnen hukkuvani työhön"), kyynistymistä (3 osiota, esim. "Tunnen itseni usein haluttomaksi työssä ja ajattelen usein lopettaa työsuhteeni") ja ammatillisen itsetunnon laskua (3 osiota, esim. 
"Kyselen alituiseen, onko työlläni arvoa"). Osioihin vastattiin 6-portaisella asteikolla (1 = täysin eri mieltä -6 = täysin samaa mieltä). Summamuuttujissa korkeat pistemäärät kuvaavat voimakkaampaa uupumusasteista väsymystä, kyynistymistä sekä ammatillisen itsetunnon laskua.

Työn imua mitattiin 9-osioisella Utrecht Work Engagement Scale -kyselyllä (Schaufeli ym. 2002). Kyselyssä mitattiin kolmea ulottuvuutta: tarmokkuutta (3 osiota, esim. "Tunnen olevani täynnä energiaa, kun teen työtäni"), omistautumista (3 osiota, esim. "Olen innostunut työstäni") ja uppoutumista (3 osiota, esim. "Kun työskentelen, työ vie minut mukanaan"). Osioihin vastattiin asteikolla 1 (ei koskaan) - 7 (päivittäin). Summamuuttujissa suurempi pistemäärä viittaa toistuviin tarmokkuuden, omistautumisen ja uppoutumisen kokemuksiin.

Työnkuvan vaihtoajatuksia johtotehtäviin liittyen pyydettiin arvioimaan kolmella eri väittämällä siten, että johtajat arvioivat uransa jatkoa seuraavien viiden vuoden aikana. Mittari kehitettiin tätä tutkimusta varten. Väittämät olivat seuraavat: "Hakeudun vaativampiin johtotehtäviin", "Hakeudun vähemmän vaativiin johtotehtäviin" sekä "Hakeudun kokonaan pois johtotehtävistä (muihin työtehtäviin)". Väittämiä arvioitiin asteikolla 1 (hyvin epätodennäköistä) - 5 (hyvin todennäköistä).

Taustamuuttujina tutkittiin (kontrolloitiin) sukupuoli ( 1 = nainen, 2 = mies), ammattitausta (professorit, tieteentekijät, ekonomit, tekniikan akateemiset) ja ikä (jatkuva muuttuja).

Muuttujien väliset korrelaatiot on koottu taulukkoon 1 ja summamuuttujien osioiden lukumäärä, vaihteluvälit, keskiarvot, keskihajonnat sekä reliabiliteetit ovat nähtävissä taulukossa 2.

\section{Tilastolliset analyysit}

Tilastolliset analyysit tehtiin IBM SPSS Statistics 24 -tilasto-ohjelmalla. Teimme k-keskiarvojen klusterianalyyseja etsiessämme aineistoista työn intensifikaation profiileja, jotka eroavat työn intensifikaation (4 muuttujaa) kokemisen suhteen toisistaan. Profiilien välisiä eroja sukupuolen ja ammattitaustan suhteen tutkimme ristiintaulukoinnilla ja $\chi^{2}$-testillä sekä eroja iän suhteen yksisuuntaisella varianssianalyysilla. Selvitimme profiilien eroja työuupumuksen ja työn imun sekä työnkuvan vaihtoajatusten suhteen yleisellä lineaarisella mallilla (GLM), jossa kontrolloitiin taustamuuttujat.

\section{Tulokset}

\section{Johtajien työn intensifikaation profiilit}

Teimme vaihtoehtoisia klusterianalyysejä kahdesta profiilista kahdeksaan. Johtajat jakautuivat parhaiten työn intensifikaation kokemisen suhteen viiteen profiiliin. Viisi profiilia erosivat työn intensifikaation ulottuvuuksien suhteen merkitsevästi $(p<0,001)$ ja jokaisessa profiilissa oli riittävästi johtajia jatkoanalyysien tekoa varten (tutkimuskysymykset 2 ja 3). Profiilit olivat sisällöllisesti mielekkäitä (kuvio 1), sillä ne toivat ilmiön yleisyyden hyvin esille sekä osoittivat ryhmien välillä olevan sisäistä vaihtelua työn intensifikaation ulottuvuuksien suhteen.

Ensimmäisen profiilin johtajilla esiintyi keskimääräistä enemmän työn intensifikaation kokemuksia, jolloin he kokivat lisääntyneitä vaatimuksia jokaisessa työn intensifikaation ulottuvuudessa (ks. kuvio 1). Nimesimme ryhmän riskiprofiiliksi. Ryhmä oli kooltaan suurin $(n=216,31 \%)$. Toisen profiilin johtajat $(n=135,19 \%)$ kokivat hieman keskimääräisesti enemmän työn ja urasuunnittelun vaatimuksia. Toisaalta he kokivat keskimääräistä selvästi vähemmän työtahdin kiristymistä, joten nimesimme ryhmän suotuisaksi profiiliksi. Kolmanteen profiiliin kuuluvilla johtajilla ( $n=140,20 \%$ ) esiintyi keskimääräistä enemmän työtahdin kiristymistä sekä lisääntyneitä tieto- ja taitovaatimuksia. He kuitenkin ko- 





Taulukko 2. Muodostettujen summamuuttujien osiot, vaihteluvälit, keskiarvot (ka), keskihajonnat (kh) ja reliabiliteetit (Cronbachin $\alpha$ )

\begin{tabular}{|c|c|c|c|c|c|}
\hline Summamuuttuja & $\begin{array}{l}\text { Osioiden } \\
\text { lkm }\end{array}$ & Vaihteluväli & $k a$ & $k h$ & Cronbach a \\
\hline \multicolumn{6}{|l|}{ Työn intensifikaatio } \\
\hline Työtahdin kiristyminen & 5 & $1-5$ & 3.79 & 0.95 & 0.87 \\
\hline Työnsuunnitteluun liittyvät vaatimukset & 5 & $1-5$ & 3.55 & 0.88 & 0.84 \\
\hline Urasuunnitteluun liittyvät vaatimukset & 3 & $1-5$ & 3.32 & 0.94 & 0.76 \\
\hline Lisääntyneet tieto- ja taitovaatimukset & 6 & $1-5$ & 3.76 & 0.84 & 0.92 \\
\hline \multicolumn{6}{|l|}{ Työuupumus } \\
\hline Uupumusasteinen väsymys & 3 & $1-6$ & 3.25 & 1.17 & 0.76 \\
\hline Kyynistyminen & 3 & $1-6$ & 2.38 & 1.13 & 0.83 \\
\hline Ammatillisen itsetunnon lasku & 3 & $1-6$ & 2.62 & 1.28 & 0.79 \\
\hline \multicolumn{6}{|l|}{ Työn imu } \\
\hline Tarmokkuus & 3 & $1-7$ & 5.56 & 1.16 & 0.89 \\
\hline Omistautuminen & 3 & $1-7$ & 5.87 & 1.11 & 0.89 \\
\hline Uppoutuminen & 3 & $1-7$ & 5.85 & 1.00 & 0.83 \\
\hline \multicolumn{6}{|l|}{ Työnkuvan vaihtoajatukset } \\
\hline "Hakeudun vaativampiin johtotehtäviin" & 1 & $1-5$ & 2.50 & 1.25 & - \\
\hline "Hakeudun vähemmän vaativiin johtotehtäviin" & 1 & $1-5$ & 1.96 & 1.01 & - \\
\hline $\begin{array}{l}\text { "Hakeudun kokonaan pois johtotehtävistä } \\
\text { (muihin työtehtäviin)" }\end{array}$ & 1 & $1-5$ & 2.06 & 1.16 & - \\
\hline
\end{tabular}

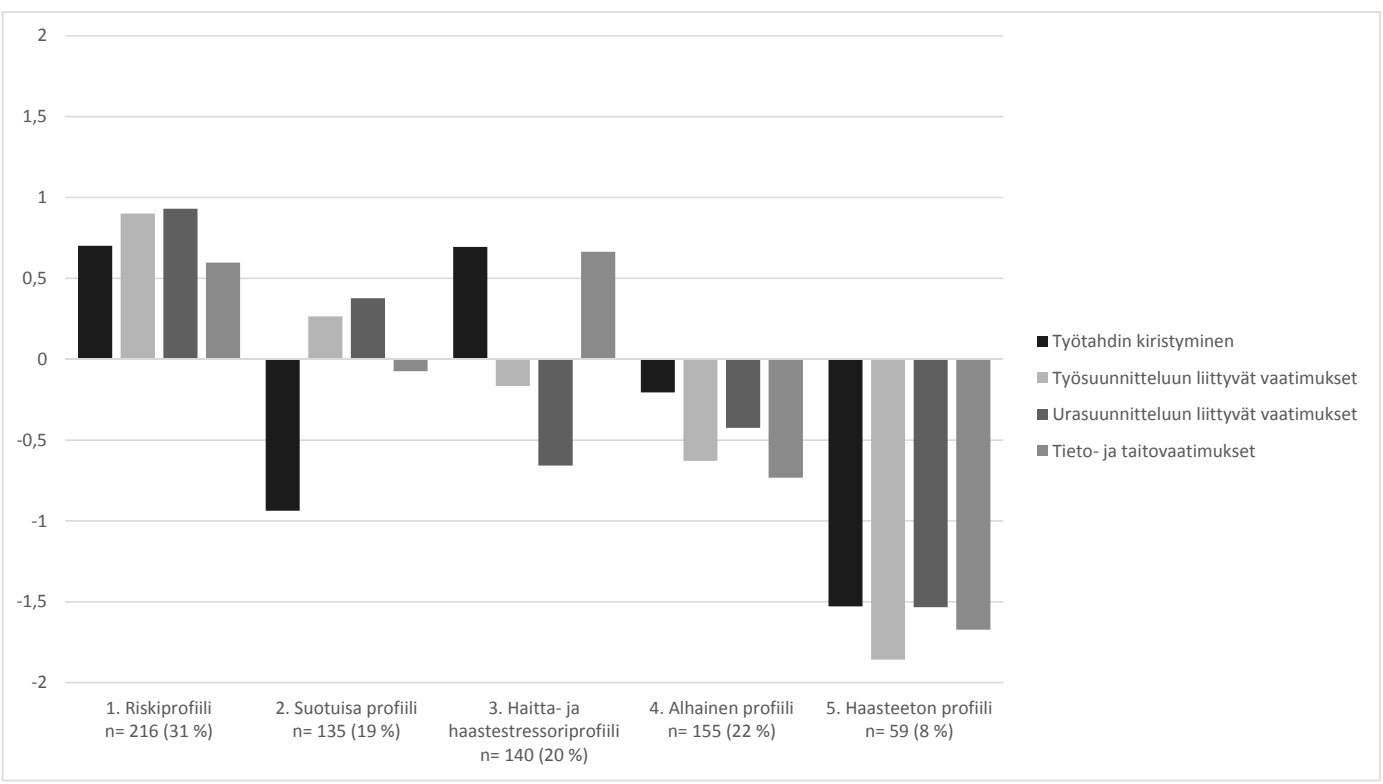

Kuvio 1. Johtajien työn intensifikaation profiilit (k-keskiarvojen klusterianalyysi). Tulkinnan helpottamiseksi kuviossa on raportoitu standardoidut summamuuttujat. 
kivat keskimääräistä vähemmän lisääntyneitä työn- ja urasuunnitteluun liittyviä vaatimuksia. Nimesimme ryhmän haitta-ja haastestressoriprofiiliksi, sillä he kokivat riskiprofiilia vähemmän työn intensifikaatiota, jolloin heillä esiintyi haittastressoreiden lisäksi mahdollisesti myös haastestressoreita. Neljännen profiilin johtajat ( $n=155,22 \%$ ) kokivat keskimääräistä hieman vähemmän työn intensifikaatiota, joten nimesimme sen alhaiseksi profiiliksi. Viidennen profiilin johtajat kokivat keskimääräistä selvästi vähemmän työn intensifikaatiota, joten nimesimme ryhmän haasteettomaksi profiiliksi. Ryhmä oli kooltaan pienin $(n=59$, $8 \%)$.

\section{Kuvailevat tulokset: erot profiileissa taustamuuttujien mukaan}

Ristiintaulukoinnista ja $\chi^{2}$-testistä selvisi, että profiileissa oli merkitseviä yli- ja aliedustuksia sukupuolen $[\chi 2(4)=41.37, \mathrm{p}<.001]$ ja ammattitaustan $[\chi 2(12)=53.88, \mathrm{p}<.001]$ mukaan. Riskiprofiilissa naiset olivat yliedustettuina (profiilissa $42 \%$ naisista), kun taas alhaisessa profiilissa miehet olivat yliedustettuina (28\% miehistä).

Suotuisassa profiilissa olivat aliedustettuina professorit (12\% professoreista) ja yliedustettuina ekonomit (30 \% ekonomeista). Haittaja haastestressoriprofiilissa olivat yliedustettuina professorit (27\% professoreista) sekä aliedustettuina ekonomit (11\% ekonomeista) ja tekniikan akateemiset ( $6 \%$ tekniikan akateemisista). Lisäksi alhaisessa profiilissa olivat yliedustettuina tekniikan akateemiset (32\% tekniikan akateemisista). Ammattitaustalla oli tilastollisesti erittäin merkitsevä yhteys profiileihin $[\chi 2(4)=41.37, \mathrm{p}<.001]$.

Yksisuuntainen varianssianalyysi osoitti johtajien iän eroavan profiileissa (df $(4,699)$ $=5.283, \mathrm{p}<0,001)$. Suotuisan profiiliin johtajat olivat nuorempia ( $k a=50.16, k a=9.54)$ verrattuna haitta- ja haastestressoriprofiilin $(k a=54.66, k h=7.19)$ ja alhaisen profiilin ( $k a=53.25, k h=8.01)$ johtajiin Games-Howellin testin parittaisten vertailujen perusteella.

\section{Johtajien profiilien erot työhyvinvoinnissa ja työnkuvan vaihtoajatuksissa}

Riskiprofiilin sekä haitta- ja haastestressoriprofiilin johtajilla esiintyi eniten työuupumusta. Riskiprofiilin ja haitta- ja haastestressoriprofiilin johtajat raportoivat merkitsevästi enemmän uupumusasteista väsymystä verrattuna muiden profiilien johtajiin (taulukko 3). Alhaisessa profiilissa oli havaittavissa enemmän uupumusasteista väsymystä kuin haasteettomassa profiilissa. Sen lisäksi riskiprofiilissa ja haittaja haastestressoriprofiilissa verrattuna suotuisaan profiiliin oli myös havaittavissa enemmän kyynistymistä. Riskiprofiilissa ja haitta- ja haastestressoriprofiilissa esiintyi eniten ammatillisen itsetunnon laskua.

Suotuisan profiilin johtajilla oli eniten työn imun kokemuksia. Suotuisassa profiilissa oli havaittavissa eniten tarmokkuutta verrattuna riskiprofiiliin, haitta- ja haastestressoriprofiiliin sekä haasteettomaan profiiliin. Suotuisan profiilin sekä haitta- ja haastestressoriprofiilin johtajat kokivat enemmän omistautumista kuin haasteettoman profiilin johtajat. Riskiprofiilissa oli enemmän uppoutumisen kokemuksia verrattuna alhaiseen profiiliin ja haasteettomaan profiiliin. Haitta- ja haastestressoriprofiilissa ilmeni enemmän uppoutumisen kokemuksia verrattuna haasteettomaan profiiliin. Lisäksi haitta- ja haastestressoriprofiilin johtajat olivat todennäköisemmin hakeutumassa vähemmän vaativiin johtotehtäviin verrattuna suotuisan ja haasteettoman profiilien johtajiin. 
Taulukko 3. Työuupumuksen, työn imun ja työnkuvan vaihtoajatusten väliset erot työn intensifikaation profiileissa (Yleinen lineaarinen malli GLM; sukupuoli, ammattitausta ja ikä kontrolloitu)

\begin{tabular}{|c|c|c|c|c|c|c|c|c|}
\hline & $\begin{array}{l}\text { 1. Riski- } \\
\text { profiili } \\
\text { ( } n=216) \\
\text { ka (kv) }\end{array}$ & $\begin{array}{l}\text { 2. Suotuisa } \\
\text { profiili } \\
\text { (n=135) } \\
\text { ka (kv) }\end{array}$ & $\begin{array}{l}\text { 3. Haitta- ja } \\
\text { haaste- } \\
\text { stressori- } \\
\text { profiili } \\
(n=140) \\
\text { ka (kv) }\end{array}$ & $\begin{array}{l}\text { 4. Alhainen } \\
\text { profiili } \\
\text { ( } n=155) \\
\text { ka (kv) }\end{array}$ & $\begin{array}{l}\text { 5. Haastee- } \\
\text { ton profiili } \\
(n=59) \\
\text { ka (kv) }\end{array}$ & F-testi & $d f 1, d f 2$ & $\begin{array}{l}\text { Bonferroni } \\
\text { parittaiset } \\
\text { vertailut }\end{array}$ \\
\hline $\begin{array}{l}\text { Uupumus- } \\
\text { asteinen } \\
\text { väsymys }\end{array}$ & $3.71(.08)$ & $2.58(.09)$ & $3.84(.10)$ & $2.97(.09)$ & $2.47(.14)$ & $38.37 * * *$ & 4,679 & $\begin{array}{l}1>2,4,5 \\
3>2,4,5 \\
4>5\end{array}$ \\
\hline Kyynistyminen & $2.52(.08)$ & $2.11(.10)$ & $2.58(.10)$ & $2.30(.10)$ & $2.19(.15)$ & $5.29 * * *$ & 4,679 & $2<1,3$ \\
\hline $\begin{array}{l}\text { Ammatillisen } \\
\text { itsetunnon lasku } \\
\text { Tarmokkuus } \\
\text { Omistautuminen }\end{array}$ & $\begin{array}{l}5.58(.08) \\
5.90(.08)\end{array}$ & $\begin{array}{l}5.93(.10) \\
6.06(.10)\end{array}$ & $\begin{array}{l}5.29(.11) \\
5.95(.10)\end{array}$ & $\begin{array}{l}5.55(.10) \\
5.75(.10)\end{array}$ & $\begin{array}{l}2.40(.17) \\
5.27(.15) \\
5.41(.15)\end{array}$ & $\begin{array}{c}7.70^{* * *} \\
5.23^{* * *} \\
4.05^{* *}\end{array}$ & $\begin{array}{l}4,679 \\
4,679 \\
4,679\end{array}$ & $\begin{array}{l}1>2,4,5 \\
3>2 \\
2>1,3,5 \\
5<2,3\end{array}$ \\
\hline Uppoutuminen & $6.01(.07)$ & $5.85(.09)$ & $5.94(.09)$ & $5.67(.09)$ & $5.45(.13)$ & $4.25 * *$ & 4,679 & $\begin{array}{l}1>4,5 \\
3>5\end{array}$ \\
\hline $\begin{array}{l}\text { Vaativampiin } \\
\text { johtotehtäviin } \\
\text { hakeutuminen }\end{array}$ & $2.62(.08)$ & $2.79(.10)$ & $2.28(.10)$ & $2.41(.09)$ & $2.20(.15)$ & 2.28 & 4,694 & \\
\hline $\begin{array}{l}\text { Vähemmän } \\
\text { vaativiin } \\
\text { johtotehtäviin } \\
\text { hakeutuminen }\end{array}$ & $1.99(.07)$ & $1.75(.09)$ & 2.19 (.09) & $1.96(.08)$ & $1.73(.13)$ & $3.86 * *$ & 4,694 & $3>2,5$ \\
\hline $\begin{array}{l}\text { Kokonaan pois } \\
\text { johtotehtävistä }\end{array}$ & $2.01(.08)$ & $1.96(.10)$ & $2.24(.11)$ & $2.17(.10)$ & $1.75(.15)$ & 1.92 & 4,694 & \\
\hline
\end{tabular}

$* \mathrm{p}<0.05, * * \mathrm{p}<0.01, * * * \mathrm{p}<0.001$

$\mathrm{ka}=$ keskiarvo, $\mathrm{kv}=$ keskivirhe

\section{Pohdinta}

Tavoitteenamme oli tunnistaa erilaisia profiileja johtotehtävissä toimivien professoreiden, tieteentekijöiden, ekonomien sekä tekniikan akateemisten työn intensifikaation kokemuksista. Profiloinnit tehtiin käyttämällä neljää kuvaajaa: työtahdin kiristyminen, lisääntyneet työnsuunnittelua ja päätöksentekoa koskevat vaatimukset, lisääntyneet urasuunnitteluun ja sitä koskevaan päätöksentekoon liittyvät vaatimukset sekä lisääntyneet tieto- ja taitovaatimukset. Tutkimuksessa tarkasteltiin työn intensifikaation profiilien yhteyttä johtajien työhyvinvointiin ja työnkuvan vaihtoajatuksiin. Hypoteesien suuntaisesti löysimme johtajien työn intensifikaation kokemuksista viisi erilaista profiilia (H1a), jotka erosivat toisistaan työhyvinvoinnin ja työnkuvan vaihtoajatusten suhteen.

\section{Lähes joka kolmas johtaja kuului työn intensifikaation riskiprofiiliin}

Hypoteesimme (H1b) mukaisesti työn intensifikaation kokeminen voimakkaana oli yleistä, sillä lähes kolmannes johtajista (31\%) kuului riskiprofiiliin, jossa koettiin lisääntyneitä työn intensifikaation vaatimuksia kaikilla neljällä osa-alueella. Tulos vahvistaa muiden tutkimusten havaintoja siitä, että työn intensifikaatio on yleinen ilmiö nykypäivän työelämässä (Burchell ym. 2002; Green \& McIntosh 2001; Paoli \& Merllié 2005,3 ) ja erityisesti juuri ylemmän tason johtajilla ja asiantuntijoilla (Gallie \& Zhou 2013; Le Fevre ym. 2015). Havaitsimme myös, että naisjohtajia oli suhteellisesti enemmän riskiprofiilissa. Tulos on ristiriidassa Euroopassa tehdyn työolosuhdetutkimuksen kanssa, joka osoitti miesten kokevan enemmän työn intensiteettiä (Eurofound 2013). Euroopassa teh- 
tyyn työolosuhdetutkimukseen osallistui kuitenkin laajasti eri aloilta työntekijöitä, eikä pelkästään johtajia, ja työn intensiteettiä mitattiin tutkimukseemme verrattuna suppeammin vain työtahdin kiristymisen sekä työpaineiden kautta. Lisäksi Burchell ja Fagan (2004) havaitsivat analysoimalla Euroopan työolosuhdetutkimusta vuodelta 2000, että Euroopassa sukupuolten väliset erot työn intensiteetin kokemisessa ovat vuosien 1991 ja 2000 välillä pienentyneet. Naisjohtajilla on ollut siis voimakkaampaa kasvua työn intensifikaatiossa kuin miesjohtajilla, mikä tukee Burchellin ja Faganin (2004) analyysiä.

Hypoteesimme mukaisesti (H2a) riskiprofiiliin kuuluvat johtajat kokivat voimakkaasti työuupumuksen kaikkia osa-alueita. Tulos oli samansuuntainen Korunkan ja kollegoiden (2015) tutkimuksen kanssa, jossa he havaitsivat työn intensifikaation olevan haittastressori, joka lisää uupumusasteista väsymystä. Myös Kubicek ja kollegat (2015) havaitsivat tutkimuksessaan työn intensifikaation ulottuvuuksien lisäävän todennäköisyyttä uupumusasteisen väsymyksen sekä kyynistymisen kokemuksiin työntekijöillä.

\section{Kohtuulliset työn intensifikaation kokemukset olivat yhteydessä työn imuun myönteisesti}

Suotuisan profiilin johtajat (19\%) kokivat kohtuullisesti lisääntyneitä työn- ja urasuunnittelun vaatimuksia, mutta vain vähän työtahdin kiristymistä. Hypoteesimme (H2b) mukaisesti suotuisan profiilin johtajat kokivat voimakkaasti työn imua, mutta eivät lähes ollenkaan työuupumusta verrattuna muihin profiileihin. Suotuisan profiilin johtajien työssä korostuivatkin haastestressorit. Tuloksemme oli samansuuntainen Karatepen ja kollegoiden (2014) tutkimuksen kanssa, joka osoitti haastestressoreiden lisäävän työntekijöiden työn imua. Tutkimustulostamme tukee myös Warrin (1987) vitamiinimalli, jonka mukaan optimaalinen autonomia lisää työhyvinvointia. Kuitenkin on huomioitava, että työhyvinvoinnin kannalta suotuisin profiili oli tutkimuksessamme kooltaan toiseksi pienin, joten olisikin tärkeää edistää entistä enemmän organisaatioissa johtajien kokemia työhyvinvointia lisääviä haastestressoreita.

Haitta- ja haastestressoriprofiilin johtajat (20\%) kokivat työtahdin kiristyneen. Heillä esiintyi profiileista eniten kokemuksia lisääntyneistä tieto- ja taitovaatimuksista. Hypoteesiemme (H2a, H2b) vastaisesti haitta- ja haastestressoriprofiilin johtajat kokivat yhtäaikaisesti haitta- ja haastestressoreita, jolloin heillä ilmeni sekä työuupumusta että työn imun osa-alueista omistautumista ja uppoutumista. Vaikka haitta- ja haastestressoriprofiilin johtajilla esiintyi riskiprofiilin johtajien tapaan paljon kokemuksia työtahdin kiristymisestä, he kokivat sen osaltaan myös haastestressorina. Mauno ja kollegat (2007) havaitsivat tutkimuksessaan kohtuullisten aikavaatimusten lisäävän uppoutumisen kokemuksia työssä, mikä vastaa tutkimuksemme haitta- ja haastestressoriprofiilia koskevia tuloksia, sillä johtajat kokivat aikavaatimukset työtahdin kiristymisessä ainakin osittain positiivisena ja työn imua lisäävänä tekijänä. Toisaalta LePinen ja kollegoiden (2004) mukaan haastestressorit voivat vaikuttaa myös kielteisesti hyvinvointiin, joten tutkimuksemme haitta- ja haastestressoriprofiilin johtajien kokemat haastestressorit eivät suojanneet heiltä työuupumukselta, vaan saattoivat osaltaan aiheuttaa sitä.

Haitta- ja haastestressoriprofiilissa oli havaittavissa todennäköisyyttä hakeutua vähemmän vaativiin johtotehtäviin verrattuna suotuisan profiilin johtajiin. Aikaisempien tutkimusten mukaisesti (Bingham ym. 2005; Cavanaugh ym. 2000) hypoteesimme sai tukea siitä, että haitta- ja haastestressoriprofiilin johtajien kokemat haittastressorit olivat yhteydessä työnkuvan vaihtoajatuksiin ja suotuisan profiilin johtajien kokemat haastestressorit vuorostaan yhteydessä vähäisempiin työnkuvan vaihtoajatuksiin (H2a, H2b).

Havaitsimme professoreiden olevan yliedustettuina haitta- ja haastestressoriprofii- 
lissa. Professorien työn kiihtymisen seuraukset näkyvät myös Pyykön $(2012,2)$ tekemässä analyysissä, jossa havaittiin, että stressi ja uupumus ovat huomattavasti yleisempiä professoreilla kuin yliopiston muulla henkilökunnalla ja että professoreiden uupumusta selittävät heikoiksi koetut vaikutusmahdollisuudet omaan työhön, liiallinen työmäärä, tutkimusajan puute, täydentävän rahoituksen hankkiminen ja hallintotehtävät. Johtajien taustatekijöihin liittyen havaitsimme myös, että haitta- ja haastestressoriprofiilin johtajat olivat keski-iältään vanhimpia, mikä selittynee osin sillä, että professorit (keski-iältään vanhin ammattiryhmä) olivat yliedustettuja kyseisessä profiilissa. Muutoin tutkimuksessamme havaitut nuorempien ja iäkkäämpien johtajien erot työn intensifikaation kokemuksissa ovat linjassa Maunon ja kollegoiden (2019) tutkimustulosten kanssa, joissa havaittiin iäkkäämpien ylempien toimihenkilöiden kokevan enemmän työn intensifikaatiota sekä lisääntyneitä tietoja taitovaatimuksia ja nuorempien vuorostaan lisääntyneitä urasuunnitteluun liittyviä vaatimuksia.

\section{Vähäiset työn intensifikaation kokemukset olivat kielteisesti yhteydessä työn imuun}

Alhaisen profiilin johtajat (22\%), jotka kokivat hyvin vähän työn intensifikaatiota, ja haasteettoman profiilin johtajat (8\%), joilla ei esiintynyt lähes lainkaan kokemuksia työn intensifikaatiosta, eivät kokeneet lähes ollenkaan työuupumusta tai työn imua verrattuna muihin profiileihin. Hypoteesimme (H1b) mukaisesti vähäiset työn intensifikaation kokemukset olivat epätyypillisiä johtajilla, sillä haasteeton profiili oli kooltaan pienin. Haasteeton profiili vahvistaakin riskiprofiilin tapaan käsitystä sitä, että työn intensifikaation kokemukset ovat yleisiä työelämässä.

Vähäiset työn intensifikaation kokemukset alhaisessa profiilissa sekä haasteettomassa profiilissa vaikuttivat työn imuun kielteisesti, jolloin johtajat eivät kokeneet haastestresso- reita työssään. Toisaalta he eivät kokeneet kielteisiä haittastressoreita, jotka lisäisivät työuupumusta. Työn vaatimusten ja voimavarojen mallin mukaan (Bakker \& Demerouti 2007) työn vaatimusten ja voimavarojen ollessa matalia työntekijöillä esiintyy matalaa kuormitusta ja keskitasoista motivaatiota työtä kohtaan. Lisäksi LePinen ja kollegoiden (2005) haaste- ja haittastressoreiden teoreettisen viitekehyksen mukaan positiivisina koetut haasteet työssä lisäävät motivaatiota työhön. Työn vaatimusten ja voimavarojen mallin sekä haaste- ja haittastressoreiden teoreettisen viitekehyksen mukaisesti on siis mahdollista, että alhaisen profiilin ja erityisesti haasteettoman profiilin johtajat eivät ole kovin motivoituneita työhönsä verrattuna muiden profiilien johtajiin. He eivät nimittäin kokeneet juuri ollenkaan työn intensifikaatiota, jolloin heidän työnsä vaatimukset sekä haastestressorit olivat muihin profiileihin verrattuna matalalla tasolla.

\section{Tutkimuksen rajoitukset ja jatkotutkimus- ehdotukset}

Tutkimukseemme liittyy muutamia rajoituksia, jotka on syytä huomioida tuloksia yleistettäessä. Tutkittavamme edustivat yksinomaan korkeakoulutettuja johtajia ja heistä yli puolet (51,3 \%) oli professoreja. Kaiken kaikkiaan sähköisen kyselyn vastausprosentit eri ammattiliittojen jäsenillä jäivät melko mataliksi, joten jos vastanneet ovat tutkimuksen kannalta keskeisissä asioissa erilaisia kuin vastaamatta jättäneet, niin vastaamatta jättäminen saattaa heikentää tutkimuksen luotettavuutta. Toisaalta kuten Baruchin ja Holtomin (2008) tutkimus osoittaa, alhaiset vastausprosentit ovat nykyään yleinen ongelma kyselytutkimuksissa. Lisäksi tutkimuksemme oli poikkileikkaustutkimus, joten ilmiöiden välisiä syy-seuraussuhteita ei voida todentaa varmoiksi. Poikkileikkaustutkimukseen ja käytettyyn kyselymenetelmään liittyen emme myöskään tiedä, mikä on ollut työn vaatimusten lähtötaso, johon tutkittavat 
nykyistä työn intensifikaation kokemustaan peilaavat.

Tulevaisuudessa olisi syytä tutkia työn intensifikaatiota monipuolisemmalla aineistolla, esimerkiksi tutkimalla alemman koulutustason omaavia työntekijöitä sekä eri johtotasoilla työskenteleviä johtajia. On todennäköistä, että eri johtotasoilla työskentelevät johtajat kohtaavat erilaisia haasteita työssään, jolloin heidän kokema työn intensifikaatio, työhyvinvointi ja työnkuvan vaihtoajatukset voivat poiketa toisistaan. Huomionarvoista oli myös se, että naisjohtajat olivat yliedustettuina työn intensifikaation riskiprofiilissa, jossa korostuivat työhyvinvoinnin ongelmat. Sukupuolten väliset erot johtajien työn intensifikaation kokemuksissa olisikin tärkeää ottaa jatkotutkimuksen kohteeksi.

Pitkittäistutkimus olisi tarpeellista toteuttaa, jotta voitaisiin selvittää työn intensifikaation ajan myötä ilmaantuvia vaikutuksia työhyvinvointiin. Havaitsimme työn intensifikaation olevan yhteydessä työn imuun osittain myös myönteisesti. Tulostamme tukee Maunon ja kollegoiden (2019) tutkimus, jossa havaittiin kohtuullisten tieto- ja taitovaatimusten olevan positiivisesti yhteydessä työn imuun. Kuitenkin Korunka ja kollegat (2015) havaitsivat tutkimuksessaan työn intensifikaation olevan vain haittastressori, joka saattaa aiheuttaa työntekijälle uupumusasteista väsymystä. Olisikin tarpeen selvittää, vaikuttaako työn intensifikaation kokeminen pitkällä aikavälillä pelkästään kielteisesti työhyvinvointiin, vai säilyvätkö sen osittain myönteiset vaikutukset työhyvinvoinnissa. Tulokset riippuvat myös siitä, mitä arvioidaan työhyvinvointina, sillä työn intensifikaation positiiviset (haaste)vaikutukset saattavat liittyä parhaiten vain yksilön motivaatioon liittyviin seurauksiin (esim. työn imu), mutta ei stressiperäisiin seurauksiin (esim. työuupumus) (ks. Mauno ym. 2019).

\section{Johtopäätökset ja käytännön suositukset}

Tutkimuksemme osoitti eri profiileihin kuuluvien johtajien kokevan lisääntyneitä työn intensifikaation vaatimuksia, jotka olivat yhteydessä heikentyneeseen työhyvinvointiin. Tutkimuksemme on linjassa aiempien tutkimustulosten kanssa, joissa on havaittu työntekijöiden kokeneen työn intensifikaatiota viime vuosikymmeninä (Burchell ym. 2002; Green \& McIntosh 2001; Paoli \& Merllié 2005, 3) sekä työn intensifikaation heikentävän työntekijöiden hyvinvointia ja lisäävän kuormitusta (Green 2004). Tutkimustuloksemme tuki LePinen ja kollegoiden (2005) kehittämää haaste- ja haittastressoreiden teoreettista viitekehystä, sillä havaitsimme haastestressoreiden olevan yhteydessä työn imuun ja haittastressoreiden olevan yhteydessä työuupumukseen ja työnkuvan vaihtoajatuksiin.

Johtajien työhyvinvointi vaikuttaa organisaation tehokkuuteen sekä alaisten työhyvinvointiin (Little ym. 2007), joten tulostemme myötä organisaatiot voivat kiinnittää aiempaa enemmän huomiota johtajien työn intensifikaatioon ja siitä aiheutuviin työuupumuksen kokemuksiin. Johtajien ja koko organisaation edun kannalta organisaatioissa tulisi huomioida työtahdin kiristyminen ja lisääntyneet tieto- ja taitovaatimukset, jolloin organisaatioissa olisi syytä pitää kiinni kohtuullisista työmääristä sekä tukea koulutusmahdollisuuksia. Organisaatioiden pyrkiessä tehostamaan toimintojaan ja lisäämään tuottavuuttaan olisi hyvä muistaa, että tämä saattaa merkitä työntekijöille suurempaa työn intensifikaatiota, jolla puolestaan on kielteisiä hyvinvointivaikutuksia työntekijöille. Lisäksi organisaatioissa olisi tärkeää kiinnittää huomiota työn intensifikaation sisältämien haastestressoreiden määrään, sillä sopivissa määrin koettu työn intensifikaatio saattaa lisätä johtajien työn imua. Toisaalta hyvin runsaat haastestressorit, kuten esimerkiksi oppimisja taitovaatimukset työssä, saattavat kääntyä haitallisiksi, joten niiden määrä on hyvä pitää 
kohtuullisena, myös johtotehtävissä toimivilla (Mauno ym. 2019).

\section{Kiitokset}

Tutkimus on osa Suomen Akatemian rahoittamaa IJDFIN-konsortiohanketta (Työn intensifikaatio ja sen hallinta itsesäätelyn voimavarojen avulla), jota johtavat Taru Feldt (projektin johtaja Jyväskylän yliopistossa; päätösnumero 308336) ja Saija Mauno (konsortiojohtaja; 308334). Tutkimuksen aineisto on kerätty osana Työsuojelurahaston Johtamisen pelko -hanketta (116163), jota johtaa Taru Feldt. Mari Huhtalan työpanosta on rahoittanut Suomen Akatemia (294428).

\section{Kirjallisuus}

Auvinen, E., Kilponen, K., Tsupari, H., Huhtala, M., Muotka, J. \& Feldt, T. (2019). Johtotehtäviin liittyvät huolenaiheet korkeasti koulutetuilla johtajilla: selittäjät, seuraukset ja alaisten kokemukset. Jyväskylän yliopiston psykologian laitoksen julkaisuja, 356. Jyväskylä: Jyväskylän yliopisto, psykologian laitos.

Bakker, A. B. \& Demerouti, E. (2007) The job demands-resources model: state of the art. Journal of Managerial Psychology 22 (3), 309-328. https://doi.org/10.1108/02683940710733115

Baruch, Y. (2004) Transforming careers: from linear to multidimensional career paths. Career Development International 9 (1), 58-73. https://doi.org/10.1108/13620430410518147

Baruch, Y. \& Holtom, B. C. (2008) Survey response rate levels and trends in organizational research. Human Relations 61 (8), 1139-1160. https://doi.org/10.1177/0018726708094863

Bergman, L. R. \& Lundh, L-G. (2015) Introduction: The person-oriented approach: roots and roads to the future. Journal for Person-Oriented Research 1 (1-2), 1-6.

https://doi.org/10.17505/jpor.2015.01

\section{Kirjoittajat}

Janette Stenman, PsM, Jyväskylän yliopisto, sähköposti: janette.stenman@gmail.com

Hanna Itkonen, PsK, opiskelija, Jyväskylän yliopisto, sähköposti:

hanna_itkonen96@hotmail.com

Elina Auvinen, PsM, tohtorikoulutettava, Jyväskylän yliopisto, sähköposti: elina.m.e.auvinen@jyu.fi

Mari Huhtala, PsT, dos., yliopistotutkija, Jyväskylän yliopisto, sähköposti:

mari.huhtala@jyu.fi

Saija Mauno, PsT, dos., yliopistotutkija (JY), professori (TAY), Jyväskylän yliopisto ja Tampereen yliopisto, sähköposti: saija.mauno@jyu.fi

Taru Feldt, PsT, dos., professori, Jyväskylän yliopisto, sähköposti: taru.feldt@jyu.fi

Bingham, J. B., Boswell, W. R. \& Boudreau, J.W. (2005) Job demands and job search among high-level managers in the United States and Europe. Group \& Organization Management 30 (6), 653-681. https://doi.org/10.1177/1059601104269527

Briscoe, J. P. \& Hall, D. T. (2006) The interplay of boundaryless and protean careers: Combinations and implications. Journal of Vocational Behavior 69, 4-18. https://doi.org/10.1016/j.jvb.2005.09.002

Brown, M. (2012) Responses to work intensification: does generation matter? The International Journal of Human Resource Management 23 (17), 3578-3595.

https://doi.org/10.1080/09585192.2011.654348

Burchell, B. \& Fagan, C. (2004) Gender and the intensification of work: Evidence from the European Working Conditions Surveys. Eastern Economic Journal 30 (4), 627-642.

Burchell, B., Ladipo, D. \& Wilkinson, F. (toim.) (2002) Job Insecurity and Work Intensification. New York, NY: Routledge.

Cascio, W. F. (1995) Whither industrial and organizational psychology in a changing world of 
work? American Psychologist 50 (11), 928-939. https://doi.org/10.1037/0003-066X.50.11.928

Cascio, W. F. (2003) Changes in workers, work, and organizations. Teoksessa W. C. Borman, D. R. Ilgen \& R. J. Klimoski (toim.) Industrial and Organizational Psychology 12. New York, NY: John Wiley \& Sons, 401-422.

Cavanaugh, M. A., Boswell, W. R., Roehling, M. V. \& Boudreau, J. W. (2000) An empirical examination of self-reported work stress among U.S.managers. Journal of Applied Psychology 85 (1), 65-74. https://doi.org/10.1037//0021-9010.85.1.65

Droogenbroeck, F. V., Spruyt, B. \& Vanroelen, C. (2014) Burnout among senior teachers: Investigating the role of workload and interpersonal relationships at work. Teaching and Teacher Education 43, 99-109.

https://doi.org/10.1016/j.tate.2014.07.005

Eurofound (2013) Women, men and working conditions in Europe. Luxemburg: Publications Office of the European Union.

Eurofound (2017) Sixth European working conditions survey - overview report (2017 update). Luxemburg: Office for Official Publications of the European Communities.

Feldt, T., Rantanen, J., Hyvönen, K., Mäkikangas, A., Huhtala, M., Pihjalasaari, P. \& Kinnunen, U. (2014) The 9-item Bergen Burnout Inventory: Factorial validity across organizations and measurements of longitudinal data. Industrial Health 52 (2), 102-112.

https://doi.org/10.2486/indhealth.2013-0059

Franke, F. (2015) Is work intensification extra stress? Journal of Personnel Psychology 14 (1), $17-27$.

https://doi.org/10.1027/1866-5888/a000120

Gallie, D. \& Zhou, Y. (2013) Job control, work intensity, and work stress. Teoksessa D. Gallie (toim.) Economic Crisis, Quality of Work, and Social Integration. Oxford: Oxford University Press, 115141.

Garhammer, M. (2002) Pace of life and enjoyment of life. Journal of Happiness Studies 3, 217-256. https://doi.org/10.1023/A:1020676100938

Green, F. (2004) Why has work effort become more intense? Industrial Relations 43 (4), 709-741. https://doi.org/10.1111/j.0019-

8676.2004.00359.x
Green, F. \& McIntosh, S. (2001) The intensification of work in Europe. Labour Economics 8 (2), 291-308. https://doi.org/10.1016/S0927-5371(01)00027-6

Hakala, J., Kaukonen, E., Nieminen, M. \& Ylijoki, O-H. (2003) Yliopisto - tieteen kehdosta projektimyllyksi? Helsinki: Gaudeamus.

Karatepe, O. M., Beirami, E., Bouzari, M. \& Safavi, H. P. (2014) Does work engagement mediate the effects of challenge stressors on job outcomes? Evidence from the hotel industry. International Journal of Hospitality Management 36 (1), 1422. https://doi.org/10.1016/j.ijhm.2013.08.003 Kubicek, B., Korunka, C., Paškvan, M., Prem, R. \& Gerdenitsch, C. (2014) Changing working conditions at the onset of the twenty-first century: Facts from international datasets. Teoksessa C. Korunka, \& P. Hoonakker (toim.) The Impact of ICT on Quality of Working Life. Dordrecht: Springer Science Business Media, 25-41.

Kubicek, B., Paškvan, M. \& Korunka, C. (2015) Development and validation of an instrument for assessing job demands arising from accelerated change: The Intensification of Job Demands Scale (IDS). European Journal of Work and Organizational Psychology 24 (6), 898-913. https://doi.org/10.1080/1359432X.2014.979160

Korunka, C., Kubicek, B., Paškvan, M. \& Ulferts, H. (2015) Changes in work intensification and intensified learning: challenge or hindrance demands? Journal of Managerial Psychology 30 (7), 786-800.

https://doi.org/10.1108/JMP-02-2013-0065

Landsbergis, P. A. (2003) The changing organization of work and the safety and health of working people: A commentary. Journal of Occupational and Environmental Medicine 45 (1), 61-72. https:// doi.org/10.1097/00043764-200301000-00014

Le Fevre, M., Boxall, P. \& Macky, K. (2015) Which workers are more vulnerable to work intensification? An analysis of two national surveys. International Journal of Manpower 36 (6), 966-983. https://doi.org/10.1108/IJM-01-2014-0035

LePine, J. A., LePine, M. A. \& Jackson, C. L. (2004) Challenge and hindrance stress: Relationships with exhaustion, motivation to learn, and learning performance. Journal of Applied Psychology 89 (5), 883-891.

https://doi.org/10.1037/0021-9010.89.5.883 
LePine, J. A., Podsakoff, N. P. \& LePine, M. A. (2005) A meta-analytic test of the challenge stressor-hindrance stressor framework: An explanation for inconsistent relationships among stressors and performance. The Academy of Management Journal 48 (5), 764-775.

https://doi.org/10.5465/amj.2005.18803921

Little, L. M., Simmons, B. L. \& Nelson, D. L. (2007)

Health among leaders: Positive and negative affect, engagement and burnout, forgiveness and revenge. Journal of Management Studies 44 (2), 243-260.

https://doi.org/10.1111/j.1467-6486.2007.00687.x

Loon, M. \& Casimir, G. (2008) Job-demand for learning and job-related learning: The moderating effect of need for achievement. Journal of Managerial Psychology 23 (1), 89-102.

https://doi.org/10.1108/02683940810849684

Maslach, C., Schaufeli, W.B. \& Leiter, M. P. (2001) Job burnout. Annual Review of Psychology 52 (1), 397-422.

Mauno, S., Kinnunen, U. \& Ruokolainen, M. (2007)

Job demands and resources as antecedents of work engagement: A longitudinal study. Journal of Vocational Behavior 70 (1), 149-171.

https://doi.org/10.1016/j.jvb.2006.09.002

Mauno, S., Minkkinen, J., Tsupari, H., Huhtala, M. \& Feldt, T. (2019) Do older employees suffer more from work intensification and other intensified job demands? Evidence from upper white-collar workers. Scandinavian Journal of Work and Organizational Psychology 4 (1), 1-13.

https://doi.org/10.16993/sjwop.60

Meyer, J. P. \& Morin, A. J. S. (2016) A person-centered approach to commitment research: Theory, research, and methodology. Journal of Organizational Behavior 37 (4), 584-612.

https://doi.org/10.1002/job.2085

Obschonka, M., Silbereisen, R. K. \& Wasilewski, J. (2012) Constellations of new demands concerning careers and jobs: Results from a two-country study on social and economic change. Journal of Vocational Behavior 80 (1), 211-223.

https://doi.org/10.1016/j.jvb.2011.08.002

Omari, M. \& Paull, M. (2015) Public sector work intensification and negative behaviors. Journal of Organizational Change Management 28 (4), 603613.

https://doi.org/10.1108/JOCM-11-2013-0225
Paoli, P. \& Merllié, D. (2005) Ten years of working conditions in the European Union. Luxembourg: European Foundation for the Improvement of Living and Working Conditions. [online]. <URL:https://www.eurofound.europa.eu/sites/default/files/ef_publication/field_ef_document/ ef00128en.pdf>. Luettu 4.6.2019.

Paškvan, M., Kubicek, B., Prem, R. \& Korunka, C. (2016) Cognitive appraisal of work intensification. International Journal of Stress Management 23 (2), 124-146.

https://doi.org/10.1037/a0039689

Paulsson, K., Ivergård, T. \& Hunt, B. (2005) Learning at work: competence development or competence-stress. Applied Ergonomics 36 (2), 135144.

https://doi.org/10.1016/j.apergo.2004.09.008

Pongratz, H. J. \& Voß, G. G. (2003) From employee to 'entreployee': Towards a 'self-entrepreneurial' work force? Concepts and Transformation 8 (3), 239-254.

https://doi.org/10.1075/cat.8.3.04pon

Pyykkö, R. (2012) Professorin työ 2012. [online]. <URL:https://www.professoriliitto.fi/@ Bin/53241/Kyselyn+tulokset.pdf $>$. Luettu 23.4.2019.

Pyöriä, P. (2005) The concept of knowledge work revisited. Journal of Knowledge Management 9 (3), 116-127.

https://doi.org/10.1108/13673270510602818

Rosa, H. (2003) Social acceleration: Ethical and political consequences of a desynchronized highspeed society. Constellations 10, 3-33.

https://doi.org/10.1111/1467-8675.00309

Rosa, H. (2013) Social Acceleration: A New Theory of Modernity. New York: Columbia University Press.

Salmela-Aro, K., Rantanen, J., Hyvönen, K., Tilleman, K. \& Feldt, T. (2011) Bergen Burnout Inventory: reliability and validity among Finnish and Estonian managers. International Archives of Occupational Environmental Health 84, 635-645. https://doi.org/10.1007/s00420-010-0594-3

Schaufeli, W.B., Bakker, A. B. \& Salanova, M. (2006) The measurement of work engagement with a short questionnaire: A cross-national study. Educational and Psychological Measurement 66 (4), 701-716.

https://doi.org/10.1177/0013164405282471 
Schaufeli, W. B., Salanova, M., Gonzáles-Romá, V. \& Bakker, A. B. (2002) The measurement of engagement and burnout: a two-sample confirmatory factor analytic approach. Journal of Happiness Studies 3, 71-92. https://doi.org/10.1023/A:1015630930326

Szollos, A. (2009) Toward a psychology of chronic time pressure. Conceptual and methodological review. Time \& Society 18 (2/3), 332-350. https://doi.org/10.1177/0961463X09337847
Ulferts, H., Korunka, C. \& Kubicek, B. (2013) Acceleration in working life: an empirical test of a sociological framework. Time \& Society 22 (2), 161-185. https://doi.org/10.1177/0961463X12471006

Valeyre, A. (2004) Forms of work intensification and economic performance in French manufacturing. Eastern Economic Journal 30 (4), 643-658.

Warr, P. (1987) Work, Unemployment, and Mental Health. Oxford: Clarendon Press. 
Janette Stenman, Hanna Itkonen, Elina Auvinen, Mari Huhtala, Saija Mauno \& Taru Feldt Intensified job demands profiles among Finnish leaders: Connections to well-being at work and job turnover intentions

This article examines what types of intensified job demands (IJDs) profile can be identified among leaders, and how leaders with different profiles differ from each other in terms of well-being and job turnover intentions. The study was based on survey data. The sample was collected from the membership registers of four Finnish trade unions: the Finnish Union of University Professors, the Finnish Union of University Researchers and Teachers, Finnish Business School Graduates, and Academic Engineers and Architects in Finland. Of the examined leaders $(N=705)$, just over half (56\%) were men. Based on K-means cluster analysis, five distinctive profiles of intensified job demands (IJDs) were identified: 1) the risk profile (high IJDs, 31\%), 2) the favourable profile (moderately high intensified job- and career-related planning demands, 19\%), 3) the hindrance and challenge stressors profile (high work intensification and intensified knowledgeand skill-related learning demands, 20\%), 4) the low profile (low IJDs, 22\%), and 5) the unchallenging profile (no IJDs, 8\%). Leaders with the risk profile or the hindrance and challenge stressors profile reported the highest amount of burnout symptoms. Leaders in the latter profile also had the most job turnover intentions. Leaders with the favourable profile experienced the highest amount of work engagement and had fewer job turnover intentions. Leaders with the low profile or the unchallenging profile experienced the lowest level of work engagement. In conclusion, it can be stated that half of the examined leaders belonged to the risk (demanding) groups (1 and 3) in terms of IJDs, where there was a greater prevalence of burnout and the desire to seek less demanding management positions. 